\title{
An Eneolithic pottery hoard from Turnišče, NE Slovenia
}

\author{
Alenka Tomaž \\ Institute of Archaeology and Heritage, Faculty of Humanities, University of Primorska, Koper, SI \\ alenka.tomaz@fhs.upr.si
}

\begin{abstract}
Pottery hoard' (ger. Keramikdepotfunde), meaning a buried group of vessels, is a wellknown term in the Bronze Age archaeology, but in Neolithic and Eneolithic archaeology the term appears only rarely. In this article, we discuss the case-study of Pit PO 118, discovered at the Turnis$\check{c}$ e site. In the past, Pit PO 118 was interpreted as a potential storage pit or as remnants of past economic activities. In the article, we consider the possibilities of a different interpretation.
\end{abstract}

KEY WORDS - Eneolithic; settlement; north-east Slovenia; pottery hoard

\author{
Eneolitski keramični depo \\ iz najdišča Turnišče, SV Slovenija
}

IZVLEČEK - 'Keramični depo', kot pokopana skupina posod, je uveljavljen termin v okviru arheologije bronaste dobe, $v$ arheologiji neolitika in eneolitika pa mu je pozornost namenjena le redko. $V$ članku predstavljamo primer jame PO 118, odkrite na najdišču Turnišče. V preteklosti je bila jama interpretirana kot potencialna shrambna jama oziroma kot sledi nekdanjih gospodarskih aktivnosti. V članku presojamo možnosti njene drugačne interpretacije.

KLJUČNE BESEDE - eneolitik; naselbina; severovzhodna Slovenija; keramični depo

\section{Introduction}

North-eastern Slovenia has been known for decades as region of numerous individual finds of stone axes and adzes, usually attributed to the Neolithic or Eneolithic periods. In last four decades, systematic archaeological surveys have revealed many new Neolithic and Eneolithic sites in both the Prekmurje and Štajerska regions. Many of them have also been excavated and published, thus enriching our knowledge regarding Neolithic and Eneolithic settlement patterns, settlement organisation and material culture (Šavel 1994; 1996; 2006). The majority of newly discovered archaeological evidence is connected to settlements or their parts in the form of dug-out pits or remains of architecture, such as post-holes etc. Especially interesting are the numerous pits or dug structures which are discovered at every Neolithic and Eneolithic site in the region. Although of dif- ferent shapes and sizes, with different contents and repertoires of material culture deposited in them, their interpretation is usually more or less the same. They are interpreted either as waste pits - rarely as abandoned storage pits - or interpreted in a general manner as the remains of past economic activities. In this article, I argue that Pit PO 118 at the Turnišče site in north-eastern Slovenia can be interpreted as a pottery hoard.

\section{The site and its surroundings}

The Prekmurje region is a geographically, culturally and ethnically defined region, located in the most northeastern part of Slovenia between the Mura River and the Rába Valley. The region is divided into three geographical sub-regions: Goričko (the hilly 
area to the north of Murska Sobota); Ravensko (the eastern flatlands stretching around the Mura) and Dolinsko (the western lowlands around Lendava). In the Dolinsko region, several sites have been discovered during systematic archaeological surveys in 2005 , and excavated in 2006 as a part of an extensive project of protective excavations on Slovenian highways. The majority of newly discovered sites revealed remains of the Eneolithic period, thus enriching our knowledge regarding Eneolithic settlement patterns in the biggest part of north-eastern Slovenia.

Turnišče is one of these sites; it is located south of the village of Renkovci and west of the town with the same name as the site. In the vicinity, within a 1-kilometre radius, four other settlement areas have been

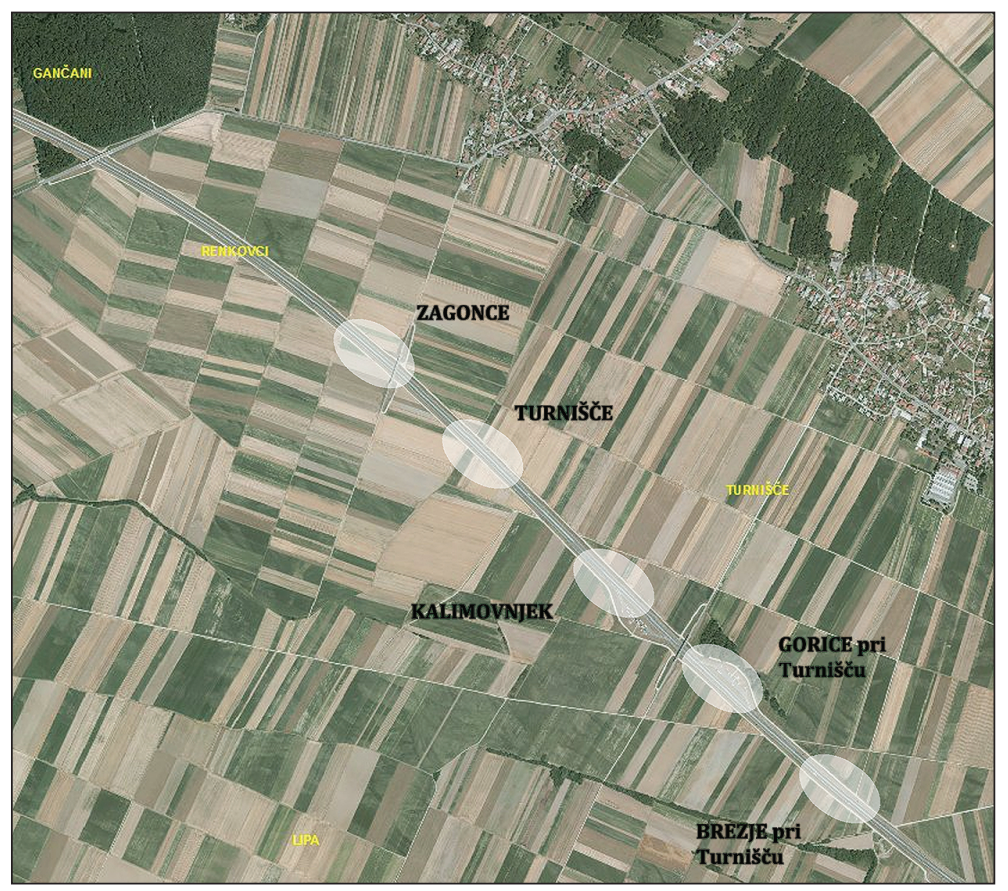

Fig.1. Location of the Turnišče sites and other Eneolithic sites in its vicinity (created by M. Zorko). identified (Zagonce, Gorice, Brezje and Kalinovnjek), covering roughly the same period of occupation as Turnišče (Fig. 1).

An archaeological team from the University of Primorska conducted a protective excavation at Turnišče in 2006, covering an area of around $16000 \mathrm{~m}^{2}$. The excavation area was limited to within the boundaries of the construction of the highway, which is why the settlement area has not been fully investigated.

The surrounding of the site is typically Pannonian, almost completely flat or slightly undulating. The site is located at approx. $175 \mathrm{~m}$ a. s. 1 . The main natu-

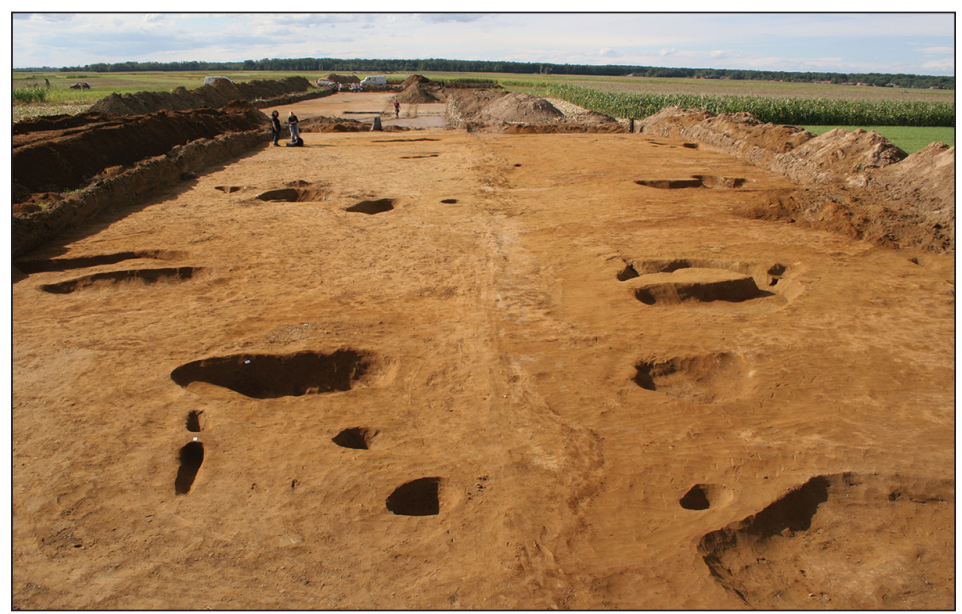

Fig. 2. Turnišče, view of the site (photo A. Ogorelec). ral resource in this area is fertile soil, thus allowing intensive agriculture to be the main activity for centuries, which has also affected the state of preservation of archaeological remains at the site. The surrounding geology of the site consists of quaternary surface deposits from the Mura River and its tributaries, with the Holocene alluvial belt alongside the Mura River thus covering an area $20 \mathrm{~km}$ wide. During excavations, it was found that the micro-morphological setting of the site is closely related to the surrounding geology and this conditioned the settlement pattern, not only within the site but also in the nearby area. The majority of archaeological remains were discovered in lightly elevated areas consisting of sand dunes, while only a few of them could be found in slightly lower areas, where pebble deposits constitute the primary geological foundation (Fig. 2). The same observation was made at all the neighbouring sites (Tomaž 2012a). Altogether, more than 160 archaeological contexts were discovered at Turnišče. There were several contexts connected with the processes of modern activities at the site; some related to the Roman settlement, but majority of archaeological remains were pits of various shapes and sizes dating to the Eneolithic period. Also, the remains of an Eneolithic cultural layer were preserved at the site (Fig. 3). 
According to the radiocarbon dates, as well as the analyses of ceramic finds, the site went through two phases of Eneolithic settlement. The remains of the First Settlement Phase can be dated to the last quarter of the $5^{\text {th }}$ millennium BC. Culturally, they can be attributed to the so-called Lasinja culture. The remains of the Second Settlement Phase can be dated to the first quarter of the $4^{\text {th }}$ millennium BC; however, culturally they can be ascribed to the horizon with furrow incision pottery' or Retz Gajary horizon (Tomaz 2012a). Among all the pits from the First Settlement Phase, pit PO 118 is the most interesting, and requires our particular attention.

\section{Pit PO 118}

Pit PO 118 was discovered in a slightly elevated section in the central part of the excavated area on its northern border. The location of the pit was somewhat isolated from the centre of the Eneolithic set- tlement, i.e. no other Eneolithic remains were found in its immediate vicinty (Fig. 3). The pit had an irregular oval ground plan, and was quite large, $3.46 \mathrm{x}$ $2.34 \mathrm{~m}$. It was dug only $0.48 \mathrm{~m}$ deep into the geological base, and filled with two different fillings; in the north-eastern part, the filling consisted mainly of pebble deposit, the north-western part contained a mixture of fine greyish-brown sand and pebbles (Tomaž 2012a.67). The filling of Pit PO 118 also included numerous pottery fragments, pieces of charcoal and burned clay, and three fragments of animal bones (unidentifiable) (Fig. 4a-c). the radiocarbon date of the charcoal sample number KIA 41443 places pit PO 118 at $5477 \pm 27 \mathrm{BP}$ (calibrated age 1- $\sigma$ : (59.4\%): 4352-4328 cal BC; calibrated age 2- $\sigma$ (69.6\%.): 4364-4316 cal BC (Tomaž 2012a.67).

\section{Description of the ceramic assemblage}

Altogether, over 680 ceramic fragments were deposited in Pit PO 118. It was one of the largest ceram-
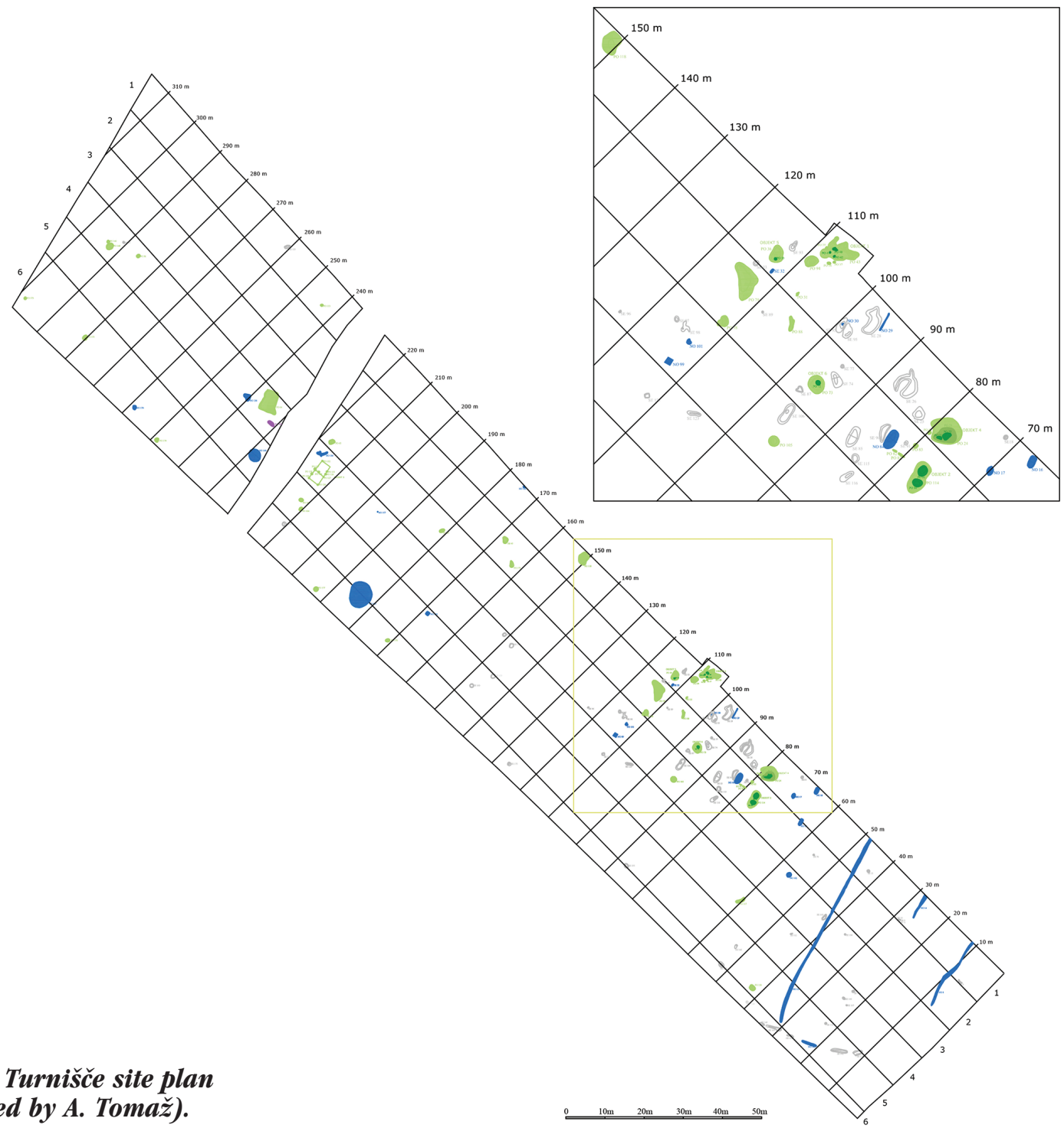
ic assemblages at the site. The assemblage is rather fragmented, but after primary processing of the finds, almost $60 \%$ of the fragments could be assembled into whole items (Tomaž 2012b.28, Fig. 23 ). We could confirm that at least 28 ceramic containers were deposited in the pit, as well as a number of fragmented vessels (Toma ̌ 2012a.27). Most of the whole containers are pots; only some are shaped as bowls and ladles (Fig. 5). The pots are generally shaped as barrel-shaped pots, with one or two handles; some are shaped as biconical pots, with two handles or without them (Figs. 11.7-11 and 12.12-16). According to the number of fragmented bases discovered in PO 118, the total number of deposited containers was much larger. We analysed the macroscopic characteristics of a sample of the ceramic assemblage, covering $50 \%$ of the total (Tomaž 2012a.268, Figs. 43-44), thus enabling a thorough insight into the ceramic technology. The macroscopic characteristics confirm that the ceramic items deposited in Pit PO 118 have similar technological traits. The majority of them were made from medium-coarse, coarse and very coarse-grained clay. Fine-grained and very fine-grained pottery account for less than $25 \%$ of the total assemblage (Fig. 6). Most commonly, quartz, mica and iron oxide particles are added to the clay (38\%), and in significant proportions also quartz and mica particles (15\%) or quartz, mica and organic particles (13\%) or quartz, mica, organic and iron oxide particles are added (11\%). Other combinations of clay additives are rare (Fig. 7). The surface of the pottery is generally smooth (67\%), which means that the potter spent quite some time removing any irregularities on the surface; only $16 \%$ of the whole ceramic assemblage has a rough surface. Combinations of different surface treatment are infrequent (Fig. 8). The majority of ceramic vessels from Pit PO 118 were fired in an oxidising atmosphere, but the process of firing was not completed (incomplete oxidising firing - 93\%). Only in rare cases was a reducing atmosphere applied toward the end of the firing process (2\%) (Fig. 9). In most cases, the pottery is undecorated (82\%) (Fig. 10 ), which is quite surprising and points towards the special selection of the deposited pottery. Socalled 'Lasinja' pottery is often decorated in a highly elaborated manner, as seen in other contexts at Turnišče (Tomaž 2012a.items no. G70-72, G77, G8284). Pottery decoration within the assemblage of Pit PO 118 consists mostly of appliqués of different shapes (Fig. 10).

In relation to other contexts of the 'First Settlement Phase' at Turnišče, PIT PO 118 shows some similar
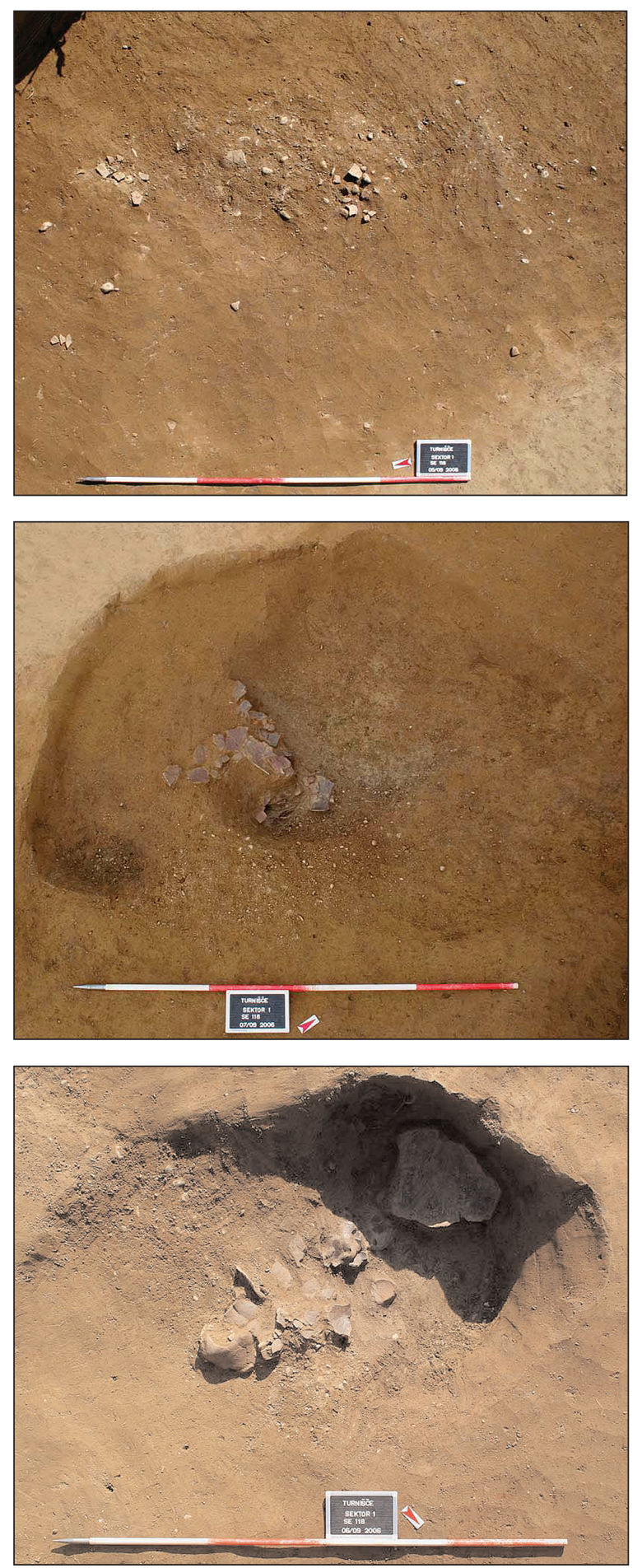

Fig. 4. Turnišče, view of PO 118, during excavations (photo A. Ogorelec).

traits regarding the pottery assemblage, but also some differences. The shapes of the pottery (Figs. 11-14), as well as their technological macroscopic characteristics fit well within other pottery assemblages of the same phase, but similar ceramics as in Pit PO 118 can also be found at other Slovenian, Hungarian, Austrian and Croatian early Eneolithic sites. In Slovenia, carinated bowls with circular knob 


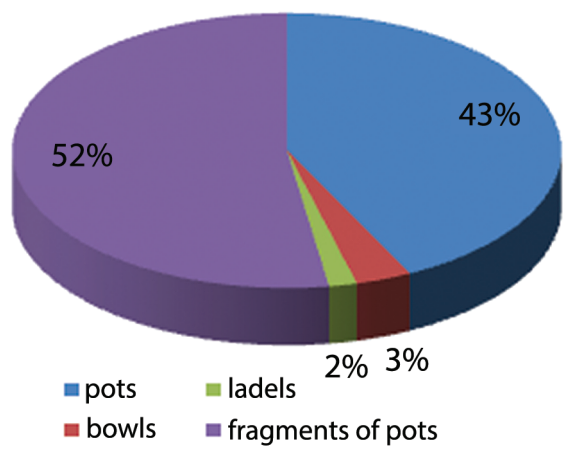

Fig. 5. Turnišče, typological characteristics of ceramic assemblage from Pit PO 118 (created by A. Tomaž).

handle (Fig. 11.1) are rare (OrmožŠkoršičev vrt (Tomanič Jevremov et al. 2006a.item no. 7)); however, they are more frequent in Hungary, at Zalaegerszeg-Andráshida, Gébárti tó (II) (Barna, Kreiter 2006. Fig. 5.2, 4), Sormás, Mántai-dúlő near Nagykanizsa (Straub 2006. Fig. 5.3; Fig. 8.1-3), Zalavár-Basasziget (Virág 2005.Tab. 3.5), Gellénháza-Városrét (Horváth, Simon 2003.Abb. 24.2, $A b b .27 .13)$ as well as at the NedelišceStara ves site in north-east Croatia $(B e-$ kic 2006.235, T. 3.2). Biconical bowls (Fig. 11.2) are known from several sites in the Pomurje and Štajerska regions, such as at Hajndl (Žižek 2006b.item no. 40), Ptujski grad (Tomanič Jevremov et al. 2006b.items no. 32, 34), Brezje near Zreče (Pahič 1956.T. 1.9) etc. They are frequent also in Hungary (e.g., Zalaegerszeg-Andráshida, Gébárti tó II (Barna, Kreiter 2006.Fig. 5.5), Dobri - Alsó-mező (Horváth, Simon 2004.Abb. 16.8, Abb. 17.3), Gellénháza-Városrét (Horváth, Simon 2003.Abb. 25.2), Zalavár-Basasziget (Virág 2005. Tab. 2.6, 9, 10, Tab. 3.1)), in north-west Croatia (Koška, pjeskana II; Markovic 1976. T.6.7) and in Austria in the Bisamberg-Oberpullendorf (Ruttkay 1995.Abb. 4.6, Abb. 6.5-8) and Kazianiberg groups (Ruttkay 1996.Abb. 1.8). Pots or jars are numerous, and for some of them there are plenty of comparisons at other early Eneolithic sites, but for some, there are only few. Comparisons for barrel-shaped pots (Figs. $11.7-11,12.12-16)$ with one or two handles are found at Hungarian sites (Sormás, Mántai-dúloó; (Straub 2006.Fig. 4.6, Fig. 4.7) and Dobri - Alsómezô (Horváth, Simon 2004.Abb. 10.18, 19, Abb. 25.3)). Biconically shaped pots (Fig. 13.22-24) are numerous at Slovenian sites (e.g., Šafarsko (Šavel 1994.Fig. 11.5, 7), Hardek (Žižek 2006a.items no. 23, 24), Bukovnica (Šavel 1994.Fig. 21.2, Fig. 20.1)), as well as at other Early Eneolithic sites (e.g., Zala-

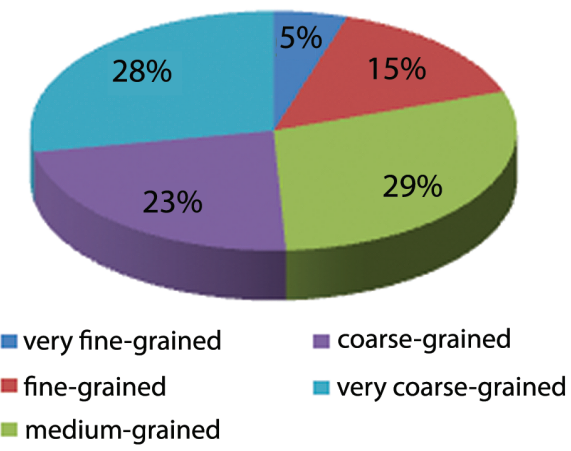

Fig. 6. Technological characteristics of ceramic assemblage from Pit PO 118 - graininess (created by A. Tomaž).

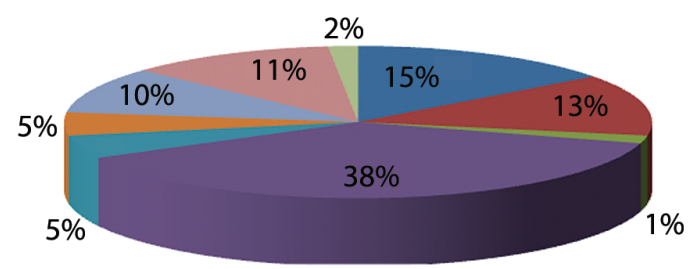

- quartz, mica, iron oxide particles, numerous particles of iron oxide - quartz, mica, iron oxide particles, some larger particles of quartz - quartz, mica, organic particles, iron oxide particles "quartz, mica, organic particles, iron oxide particles, numerous particles of mica

" quartz, mica - quartz, mica, organic particles quartz, mica, iron oxidep numerous particles of mica

Fig. 7. Technological characteristics of ceramic assemblage 118 - inclusions (created by A. Tomaž).

egerszeg-Andráshida, Gébárti tó II (Barna, Kreiter 2006.Fig. 8.4), Sormás, Mántai-dúlố (Straub 2006. Fig. 4.4), Zalavár-Basasziget (Virág 2005.Tab. 6.4), Gellénháza-Városrét (Horváth, Simon 2003.Abb. 23.8), Zalaszentbalás-Pusztatetô (Bánffy 1996.Tab. 26.1-2), Pórszombat-Medes (Horváth, Simon 2003. Abb. 27.16), Tekenye-Öcse (Horváth, Simon 2003. Abb. 27.15) and Jakšić (Dimitrijević 1961.items no. $45 d, 45 e$ ) etc.). Ceramic ladles are one of the most common finds at Neolithic as well as early Eneolithic sites in the region and the comparisons are numerous (Tomaž 2012a.35-36).

\section{Discussion and conclusion}

The ceramic repertoire of Pit PO 118 fits very well within material culture of the First Phase of the settlement at Turnišče, as well as within early Eneolithic material culture of the last quarter of the $5^{\text {th }}$ millennium BC. What differentiates the context of Pit PO 118 from other archeological contexts at Turnišče are its different deposition practices, as well as a clear selection of deposited ceramic items. Pit PO 118 contained numerous whole pots of similar, almost identical shapes and similar sizes, of similar technological characteristics, mostly undecorated. 


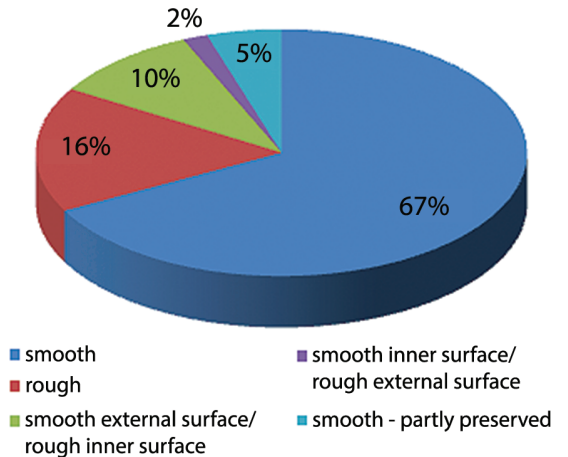

Fig. 8. Technological characteristics of ceramic assemblage from Pit PO 118 - surface treatments (created by A. Tomaž).

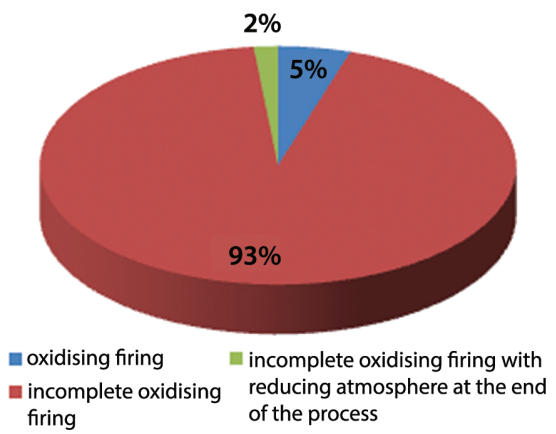

Fig. 9. Technological characteristics of ceramic assemblage from Pit PO 118 - firing techniques (created by A. Tomaž).

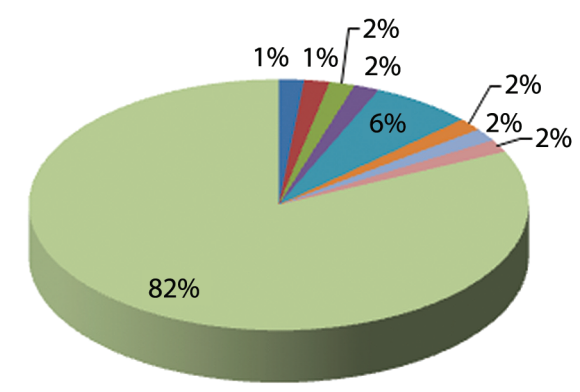

\begin{tabular}{|c|c|}
\hline grooves & = tounge-shaped thickering \\
\hline fingertip impression & a circular knob handle \\
\hline $\begin{array}{l}\text { applique - grooves - tool impression } \\
\text { oval applique }\end{array}$ & $\begin{array}{l}\text { - circular knob handle with } \\
\text { tounge-shaped applique }\end{array}$ \\
\hline plique & undecorated \\
\hline
\end{tabular}

Fig. 10. Technological characteristics of ceramic assemblage from Pit PO 118 - decoration techniques (created by A. Tomaž).

According to fragmentation analysis, the assemblage has the highest proportion of matching fragments (59.30\%). Only the assemblage from Pit PO 174 has a similar degree of fragmentation (54\%); all other archaeological contexts of the first settlement phase at Turnišče have a ratio of fragments matching around or below $20 \%$, while the assemblage from Eneolithic layer has levels below 10\% (Tomaž 2012b. 28, Fig. 23). Depending on the size of each ceramic fragment in the ceramic assemblage of Pit PO 118, we can also assume that this deposit can be regarded as so-called 'original waste', according to Macháček's categorisation (Macháček 2001), meaning that it was deposited in situ.

As already noted, according to the level of fragmentation, there is another interesting example at Turnišče. Pit PO 174 is one of the smallest pits at the site, measuring only $0.8 \mathrm{~m}$ in diameter and $0.16 \mathrm{~m}$ in depth. It had a circular ground plan and U-shaped cross-section. Its location was even more isolated than PO 118 on the southwestern border of the excavation area, far away from other Eneolithic contexts. The filling of the pit consisted of greyish black sand with numerous ceramic fragments, as well as a stone pounder, one of three stone tools discovered at the site. The filling of pit PO 174 contained 165 ceramic fragments. The degree of fragmentation of each ceramic assemblage (PO 118 and PO 174) is comparable (Tomaž 2012b.28, Fig. 23). In Pit PO 174, however, only two complete pots were deposited, as well as parts of several other ceramic containers (at least 13), a miniature bottle and a fragment of a ceramic ladle (Tomaž 2012a.items no. G62-G78). In general, the variety as well as the number of deposited pots of the whole ceramic assemblage of Pit PO 174 is much lower than in Pit PO 118. Nevertheless, it appears that the deposition practices of pits PO 118 and PO 174 were similar, yet different from other pits and structures at the Turnišče site. In one of the previous publications about the site (Tomaž 2012b.29), we interpreted Pit P0 118, based on known data, as a potential remnant of an abandoned storage pit; however, not all the evidence fits well within this interpretation. After careful deliberation of all the acquired data, we would like to propose that Pit PO 118 should perhaps be seen as a pottery hoard.

Pottery hoards (ger. Keramikdepotfunde), meaning groups of buried vessels, are well known in Bronze Age archaeology; but rarely appear in Neolithic and Eneolithic archaeology. Pottery hoards are defined as closed contexts consisting of varying amounts of pottery vessels and, frequently, also of other types of material as well. The majority of pottery hoards are discovered within settlements, in dugout structures/pits. They can contain complete or broken vessels, as well as only certain parts of vessels. Vessels can often be found in an inverted position or lying on the side (Stapel 1999). The term 'pottery hoard' is not new; it appeared as early as the 1930s (Palátová, Salaš 2002.8-9), but the number of published finds interpreted as pottery hoards increased only 
at the end of the $20^{\text {th }}$ and the beginning of the $21^{\text {st }}$ century (Karavanić 2011). According to Snježana Karavanić, pottery hoards can be found in Copper Age settlements, but are particularly numerous in the Bronze Age (Karavanic 2011.16). To define a 'closed' archaeological context containing a collection of pottery vessels buried in a pit is usually not difficult; however, interpreting them is often challenging because they can be interpreted either as storage pits, waste pits or in some instances also as pottery hoards. It is sometimes difficult to decide between these potential interpretations, especially if contextual data are lacking1. Over the years, the debate on this topic defined some criteria based on which groups of finds can be defined as pottery hoards (Karavanic 2011.16). According to Andrea Stapel, the criteria comprise the location of the find (specific geographic features, e.g. caves), accumulation of similar finds in a limited area, atypical finds in a pit, use of fire, special treatment of items (intentional destruction, intentional arrangement) etc. (Stapel 1999.18-19). As Karavanić already noted, the majority of authors, dealing with this topic agree that pottery hoards are probably material remains of ritual activities, and have been interpreted in various ways as material remains of libations, building sacrifices, ritual feasts or other forms of worship etc. (Palátová, Salaš 2002.145-153; Karavanić 2011. 17); therefore, the so-called 'sealing of the pit' as a closing part of a certain ritual activity may be an important feature with regard to pottery hoards as well (Stapel 1999). Another important criterion when considering pottery hoards was given by Lindinger (Lindinger 1998-1999.79-87); it concerns the combination of vessels according to their functions. His study revealed that the most numerous combination of vessels in Bronze Age pottery hoards in Lower Austria is of drinking vessels (small jugs and cups), followed by a combination of storage vessels, although in general there are quite varied assortments of different combinations in individual cases (Lindinger 1998-1999.Taf. 2).

If we consider the aforementioned criteria, Pit PO 118 meets quite a lot of them. First, is its location within the settlement area. The location of P0118 was somewhat isolated from the centre of the settlement, and at the beginning of the slightly elevated area. No other Eneolithic structures were in its immediate vicinity. Although its ground plan was quite large, Pit PO 118 was rather shallow, which is why the vessels were very carefully positioned in the centre of the pit. Although evidence of 'sealing of the pit' is also a very important criterion, there is no such evidence regarding PO 118: the upper part of the pit was damaged due to intensive modern agricultural activities on the site. The criterion 'accumulation of similar finds in a limited area' was confirmed through detailed analyses of the ceramic assemblage in Pit PO 110. Also, the selection of vessels deposited is in evidence, given the similar typological as well as technological and ornamental traits of the vessels. Most of them are pots or jars (types of storage vessel) and it appears that they also were pre-selected according to size; namely, measurements of their volumes 2 showed that most of them range between 4 and 6 litres; only two of them were bigger. Another important observation of the PO 118 ceramic assemblage, as already mentioned, is its fragmentation. The ceramic assemblage of Pit PO 110 has the highest rate of matching fragments of all the Eneolithic structures discovered at Turnišče, confirming that the deposition practice employed upon the formation of Pit PO 118 differed from all other structures at Turnišče, thereby showing its exceptional character.

When observing data regarding Pit PO 118, several different interpretations were considered. One of them was very general; we regarded PO 118 as the remains of past economic activities; another was somewhat more refined: we regarded PO 118 as a potential remnant of an abandoned storage pit, but when taking into consideration all the aforementioned criteria regarding 'pottery hoards', Pit PO 118 meets quite a lot of them. Although the archaeological context in question was formed in the Eneolithic period, and archaeological interpretations of such structures as 'pottery hoards' are almost nonexistent, we would like to stimulate other researchers to think within this frame as well.

1 Karavanić discussed these instances in detail (see Karavanić 2011.16-17).

2 To avoid miscalculations, only whole containers were analysed. Altogether, the volumes of 12 pots were measured. 

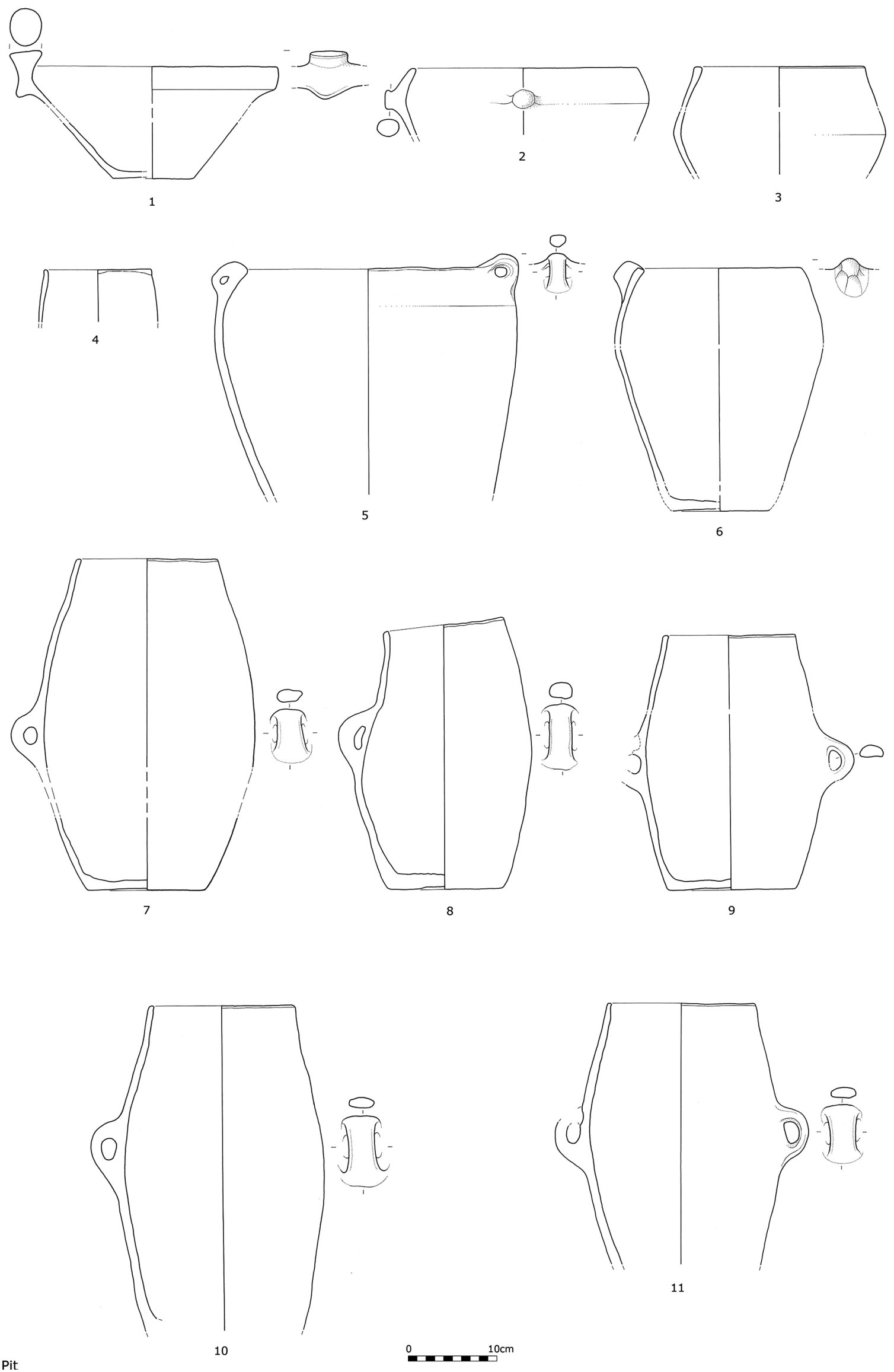

11

Pit

Fig. 11. Ceramic finds from Pit PO 118 (drawing J. Tratnik Šumi). 


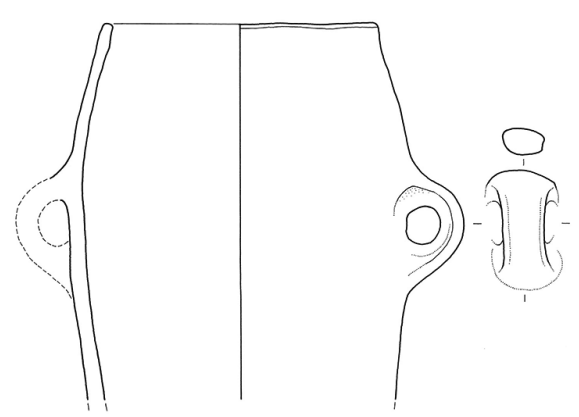

12

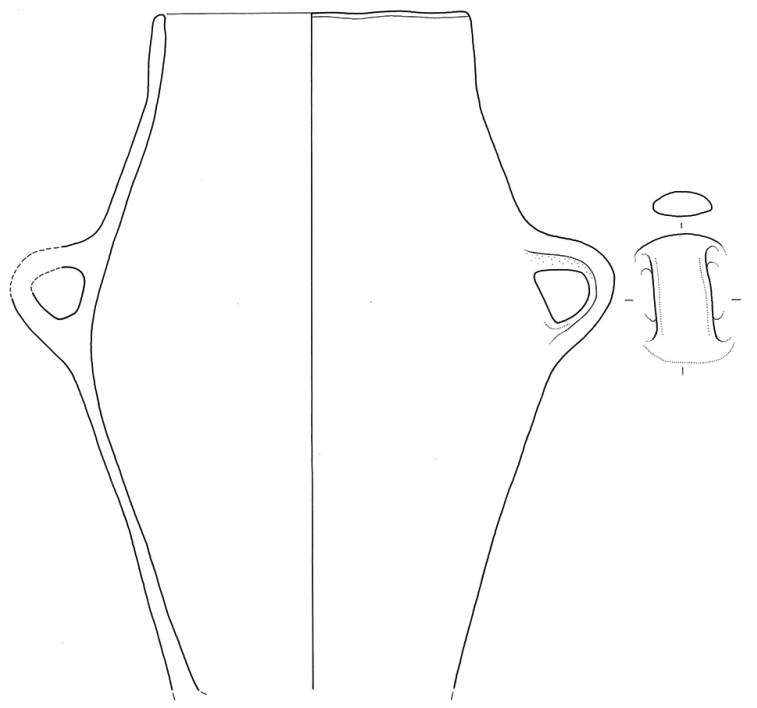

13

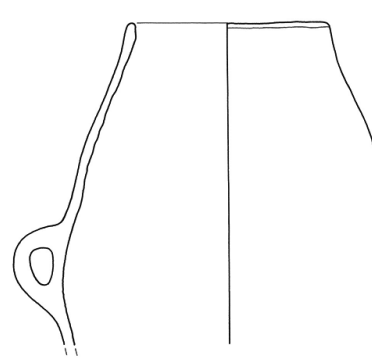

14

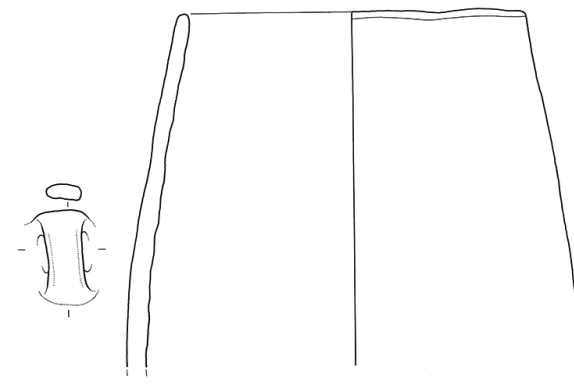

15
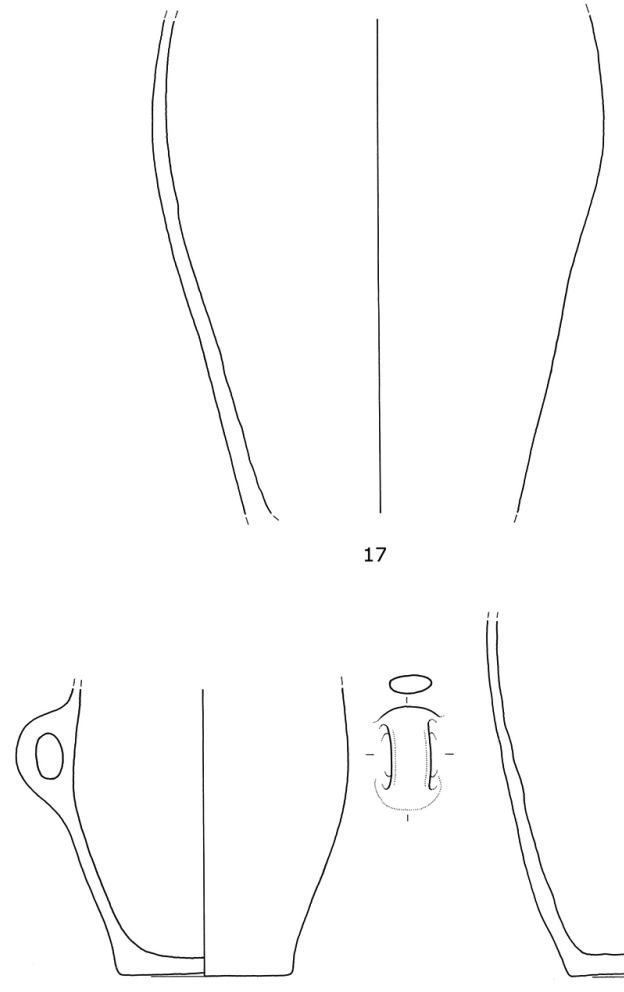

18
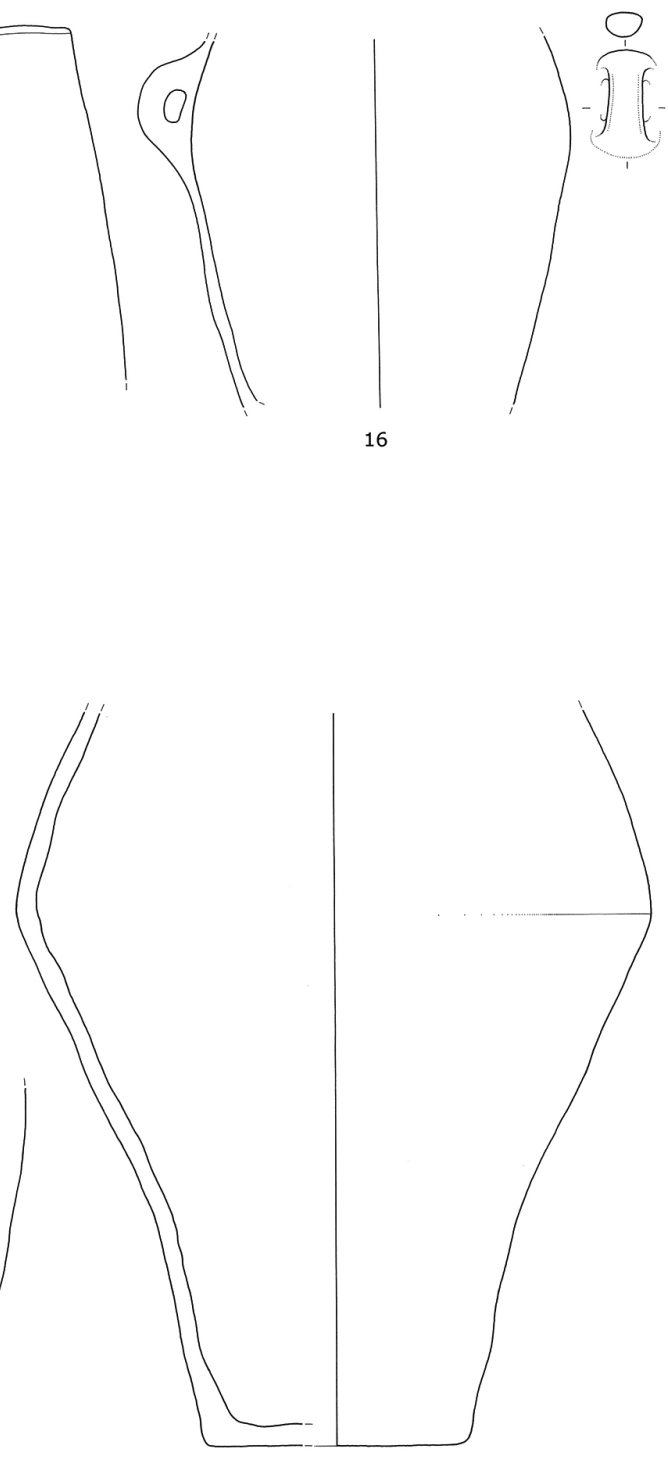

19

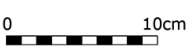

Fig. 12. Ceramic finds from Pit PO 118 (drawing J. Tratnik Šumi). 

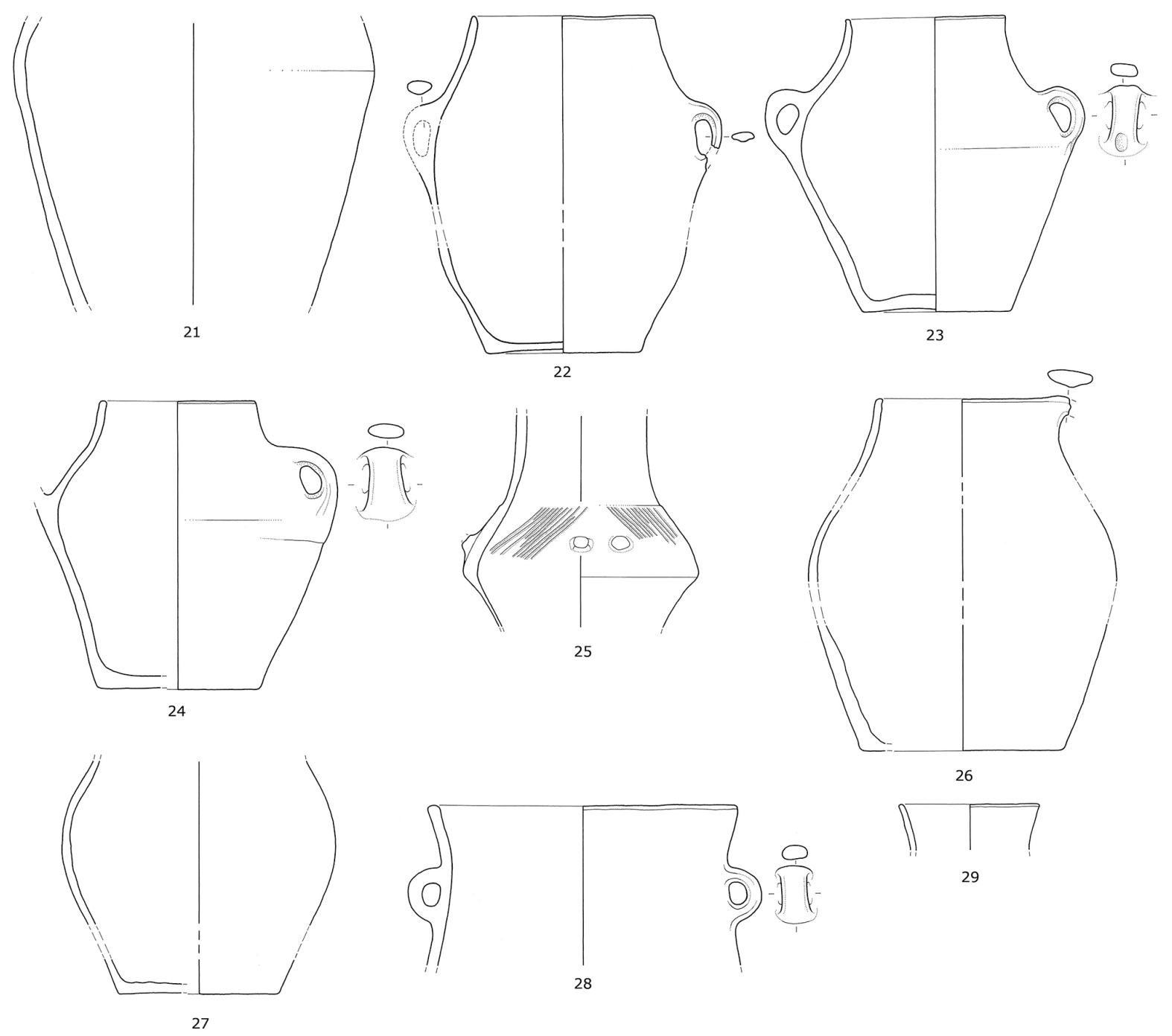

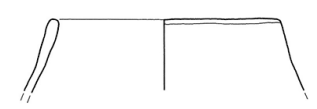

30

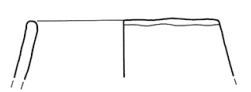

31

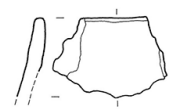

32

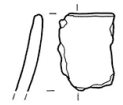

33

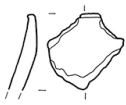

34

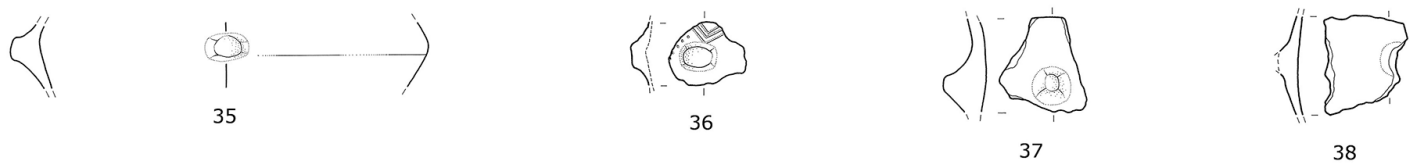

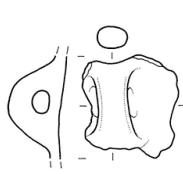

39

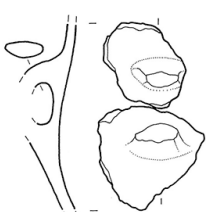

44

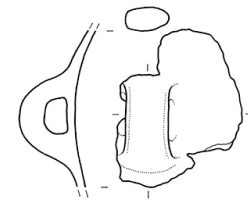

40

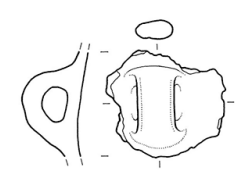

41
$C$

42

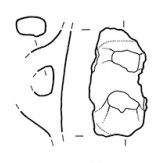

43
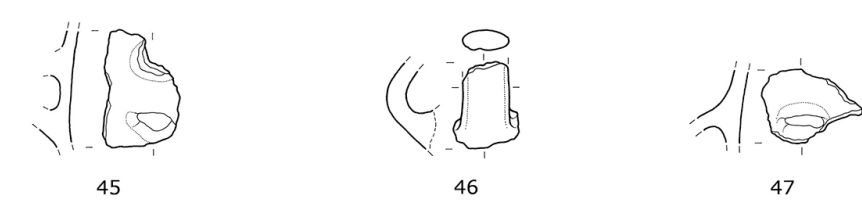

Fig. 13. Ceramic finds from Pit PO 118 (drawing J. Tratnik Šumi). 


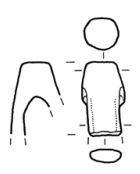

48

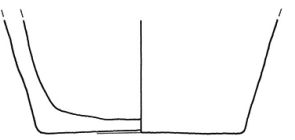

50

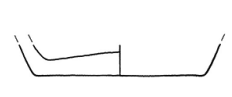

54

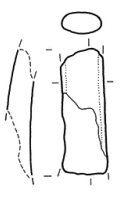

49

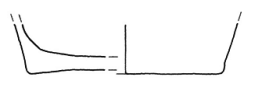

51

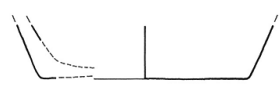

52

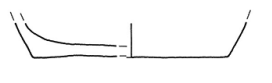

53

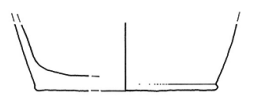

57

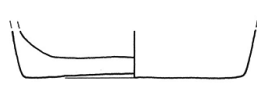

58

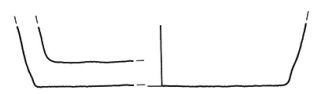

59

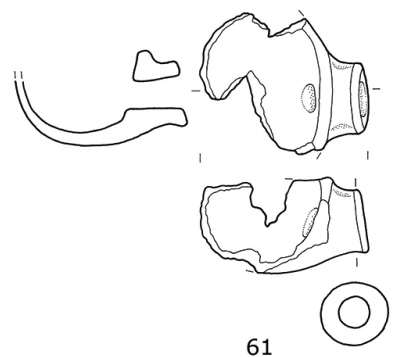

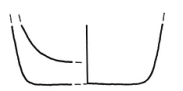

60

Fig. 14. Ceramic finds from Pit PO 118 (drawing J. Tratnik Šumi).

$\therefore$

\section{References}

Bánffy E. 1996. Újkókori és rézkori települések Hahót és Zalaszentbalás határában. Zalai Muzeum 6: 97-147.

Barna P. J., Kreiter E. 2006. Középső rézkori települések Zalaegerszeg-Andráshida, Gébárti-tó (II.) lelóhelyen, Előzetes közleménzy. Zalai Muzeum 15: 47-92.

Bekić L. 2006. Zaštitna arheologija u okolici Varaždina. Arheološka istraživanja na autocesti Zagreb-Goričan i njezinim prilaznim cestama. Ministarstvo kulture Republike Hrvatske. Zagreb.

Dimitrijević S. 1961. Problem neolita in eneolita u sjeverozapadnoj Jugoslaviji. Opuscula archaeologica 5: 5-78.

Horváth L. A., Simon K. H. 2003. Das Neolithikum und die Kupferzeit in Südwesttransdanubien, Siedlungsgeschichte und Forschungsstand. Inventaria Praehistorica Hungariae 8. Budimpešta.

2004. Kupferzeitliche Siedlungen auf dem Fundort Dobri - Alsó-mező. Zalai Múzeum 13: 55-118.
Karavanić S. 2011. Ostava keramike s lokaliteta KalnikIgrišč II. Prilozi Instituta za arheologiju u Zagrebu 28: 5-30.

Lindinger V. 1998-1999. Mittelbronzezeitliche Gefäßdeponierung von Zwerndorf an der March, NÖ. Archäologie Österreichs 9/10: 78-87.

Macháček J 2001. Studie k velkomoravské keramice. Metody, analýzy a syntézy, modely. Ústav archeologie a muzeologie. Filozofická fakulta Masarykovy univerzity v $\mathrm{Br}$ ně. Brno.

Marković Z. 1976. Problem eneolita u Našičkoj regiji. $A r$ heološki vestnik 27: 42-67.

Pahič S. 1956. Neolitske jame v Brezju pri Zrečah. Arheološki vestnik 7(2): 227-241.

Palatova H., Salaš M. 2002. Depoty keramických nádob doby bronzové na Moravé a v sousedních zemích. Pravék, Suplementum 9. Ústav archeologické památkové péče. Brno. 
Ruttkay E. 1995 (1999). Spätneolithikum. In E. Lenneis, C. Neugebauer-Maresch and E. Ruttkay (eds.),Jungsteinzeit im Osten Österreichs. Wissenschaftliche Schriftenreihe Niederösterreich 102/103/104/105 (=Forschungsberichte zur Ur- und Frühgeschichte 17): 108-177.

1996. Zur Chronologie der Kanzianiberg-Lasinja-Gruppe. Archäologie Österreiches 7(2): 43-47.

Stapel A. 1999. Bronzezeitliche Deponierungen im Siedlungsbereich. Tübinger Schriften zur Ur und Frühgeschichtlichen Archäologie. Band 3. Waxmann. Münster, New York, München, Berlin.

Straub P. 2006. Középsô rézkori települées Sormás határában: Middle Copper Age settlement at Sormás. Régészeti kutatások Magyrországon 2005: Archaeological Investigations in Hungary 2005. Kulturális Örögségvédelmi Hivatal és a Magyar Nemzeti Múzeum. Budapest: 33-60.

Šavel I. 1994. Prazgodovinske naselbine v Pomurju. Zbirka Monumenta Pannonica. Pomurska založba. Murska Sobota.

1996. Kulturni vplivi v prazgodovini v pokrajini ob Muri. In Balažic J., Vándor L. (eds.), Ljudje ob Muri; Zbornik referatov mednarodne znanstvene konference $v$ Lendavi 10.-12. maj 1995. Murska Sobota, Zalaegerszeg: 13-44.

2006. Prekmurje v mlajši kameni dobi. In Tomaž A. (ed.), Od Sopota do Lengyela, prispevki o kamenodobnih in bakrenodobnih kulturah med Savo in Donavo. Annales Mediterranea. Koper: 89-94.
Tomanič Jevremov M., Tomaž A., and Kavur B. 2006a. Ormož - Škoršičev vrt. In Tomaž A. (ed.), Od Sopota do Lengyela, prispevki o kamenodobnih in bakrenodobnih kulturah med Savo in Donavo. Annales Mediterranea. Koper: $155-174$.

2006b. Neolitske in bakrenodobne najdbe s Ptujskega gradu. In Tomaž A. (ed.), Od Sopota do Lengyela, prispevki o kamenodobnih in bakrenodobnih kulturah med Savo in Donavo. Annales Mediterranea. Koper: 175-194.

Tomaž A. 2012a. Turnišče. Zbirka Arheologija na avtocestah Slovenije 28. Zavod za varstvo kulturne dediščine Slovenije. Ljubljana.

2012b. Na sipinah preteklosti, o poselitvi v okolici Turnišča v 5. in 4. tisočletju pr. $n$. št. Annales Mediterranea. Koper.

Virag M. S. 2005. Középsố rézkori kerámialeletek ZalavárBasaszigetrôl (A Balaton-Lasinja kultúra tipológiájának és belső kronológiájának kérdéseirlől. Zalai Múzeum 14: 37-52.

Žižek I. 2006a. Bakrenodobna naselbina Hardek. In Tomaž A. (ed.), Od Sopota do Lengyela, prispevki o kamenodobnih in bakrenodobnih kulturah med Savo in Donavo. Annales Mediterranea. Koper: 129-140.

2006b. Hajndl pri Ormožu, naselje bakrene dobe. In Tomaž A. (ed.), Od Sopota do Lengyela, prispevki o kamenodobnih in bakrenodobnih kulturah med Savo in Donavo. Annales Mediterranea. Koper: 141-153.

\section{back to contents}

